\title{
SISTEM PENDUKUNG KEPUTUSAN SELEKSI PENERIMA BEASISWA PADA SMKN 8 PADANG DENGAN MENGGUNAKAN METODE WEIGHTED PRODUCT (WP)
}

\section{Yumai Wendra, Irfan Fadhli, Agung Putra Yunanda, Hilda Rahmawati, Budi Nugraha}

Universitas Pembinaan Masyarakat Indonesia

Email: yumai.wendra22@,gmail.com

Email: irfanfadhli74@gmail.com

Email: agungputrayunanda69@gmail.com

Email: hildarahma2708@gmail.com

Email: budinugraha988@gmail.com

\begin{abstract}
Abstrak
Disetiap lembaga pendidikan khusunya sekolah banyak sekali beasiswa yang ditujukan kepada siswa, baik yang layak maupun yang kurang mampu. Beasiswa ditujukan untuk membantu meringankan beban biaya siswa yang mendapatkanya. Untuk memperoleh beasiswa tersebut harus sesuai dengan kriteria-kriteria yang telah ditetapkan. Begitu juga kepada SMKN 8 Padang, juga terdapat program beasiswa yang ditujukan kepada siswa, baik yang layak maupun yang kurang mampu dan tentunya berdasarkan kriteria yang telah ditetapkan. Untuk membantu pihak sekolah menentukan siswa yang berhak menerima beasiswa, maka dapat digunakan sebuah Sistem Pendukung Keputusan (SPK), dimana salah satu metode keputusan yang dapat digunakan adalah metode Weighted Product (WP). Weighted Product suatu metode yang digunakan untuk mencari siswa optimal dari sejumlah siswa dengan kriteria tertentu. Hasil dari penelitian ini adalah sebuah aplikasi SPK yang dirancang dengan menggunakan bahasa pemrograman Visual Basic Net yang dapat membantu pihak sekolah dalam menentukan siapa yang berhak menerima beasiswa berdasarkan kriteria-kriteria serta bobot yang telah ditentukan.
\end{abstract}

Kata kunci : SPK, Menentukan Penerima Beasiswa, WP, VB Net, MySQL

RECIPIENT SELECTION DECISION SUPPORT SYSTEM SCHOLARSHIP IN

SMKN 8 PADANG USING THE METHOD WEIGHTED PRODUCT (WP)

\section{Abstract}

In every educational institution, especially schools, a lot of scholarships are aimed at students, both those who are deserving and the less fortunate. Scholarships are intended to help ease the cost burden of students who get it. To 
obtain the scholarship must be in accordance with predetermined criteria. Likewise for SMKN 8 Padang, there is also a scholarship program aimed at students, both who are deserving and who are less fortunate and of course based on predetermined criteria. To help schools determine which students are entitled to receive scholarships, a Decision Support System (SPK) can be used, where one of the decision methods that can be used is the Weighted Product (WP) method. Weighted Product is a method used to find optimal students from a number of students with certain criteria. The result of this research is an SPK application designed using the Visual Basic Net programming language which can assist the school in determining who is entitled to receive scholarships based on predetermined criteria and weights.

Keywords: SPK, Determining Scholarship Recipients, WP, VB Net, MySQL

\section{PENDAHULUAN}

Pada SMKN 8 PADANG, terdapat program pemberian beasiswa bagi siswasiswanya. Beasiswa harus diberikan kepada penerima yang layak dan pantas untuk mendapatkannya. Akan tetapi, dalam melakukan seleksi beasiswa tersebut tentu akan mengalami kesulitan karena banyaknya pelamar beasiswa dan adanya beberapa kriteria yang digunakan untuk menentukan siapa penerima beasiswa yang sesuai dengan yang diharapkan. Tidak semua yang mendaftarkan diri sebagai calon penerima beasiswa akan diterima, hanya yang memenuhi kriteriakriteria saja yang akan memperoleh beasiswa tersebut.

Proses seleksi penerima beasiswa pada SMKN 8 PADANG masih dilakukan secara manual. Sehingga masih sering terdapat kelemahan dan kesalahan salah satunya kurang tepat atau salah sasarannya penyaluran beasiswa tersebut. Hal ini terjadi karna pihak yang diberi kepercayaan dalam pengambilan keputusan melihat kriteria-kriteria yang ditentukan secara terpisah dan juga dipengaruhi oleh jumlah data calon penerima beasiswa yang masuk serta kesalahan informasi yang diterima atau diperoleh oleh pihak tersebut.

Proses pembuatan sistem pendukung keputusan untuk menentukan penerima beasiswa di SMKN 8 PADANG mengggunakan metode Weighted Product (WP). Metode ini merupakan salah satu metode pengambilan keputusan yang menggunakan perkalian untuk menghubungkan rating setiap atribut, dimana rating atribut harus dipangkatkan dulu dengan bobot atribut yang bersangkutan. Metode ini dipilih karena mampu menyeleksi alternative terbaik dari sejumlah alternatif, dalam hal ini alternatif yang dimaksudkan yaitu yang berhak menerima beasiswa berdasarkan kriteria-kriteria yang ditentukan.

Diharapkan sistem yang dibuat mampu memberikan hasil yang baik sesuai dengan perhitungan yang digunakan, membantu mempercepat pihak sekolah dalam penyeleksian penerima beasiswa, dan juga sistem dapat mengurangi kesalahan dalam menentukan penerima beasiswa.

Berdasarkan hal di atas maka penulis membahas dan mengembangkan sistem pengolahan data siswa yang ada pada SMKN 8 PADANG yang disusun 
dalam bentuk skripsi dengan judul : "SISTEM PENDUKUNG KEPUTUSAN SELEKSI PENERIMA BEASISWA PADA SMKN 8 PADANG DENGAN MENGGUNAKAN METODE WEIGHTED PRODUCT(WP)"

\section{METODE PENELITIAN}

\section{Analisa Sistem}

Analisa sistem dilakukan untuk mengetahui dan menentukan masalah yang sebenarnya, sistem yang telah ada atau sistem yang sedang berjalan sekarang penting untuk dianalisa, karena merupakan suatu perencanaan sistem yang akan direkayasa nantinya dan pada sistem yang lama ini akan dijadikan perbandingan, pengkoreksian serta pengembangan kearah perekayasaan sistem yang baru.

Dengan merencanakan sistem yang baru tujuan dapat mengoptimalkan fungsi-fungsi yang dimiliki sistem sekarang serta diharapkan berfungsi lebih baik dari pada sebelumnya.Untuk itu dianalisakan secara ringkas tentang bagaimana prosedur dari aliran sistem informasi datanya.

Pada bab ini akan dijelaskan gambaran dari proses pengambilan keputusan pemberian beasiswa pada SMKN 8 Padang. Dimana sistem pengambilan keputusan pemberian beasiswa masih dilakukan secara manual, sehingga keputusan yang dihasilkan tidak akurat. Proses pengambilan keputusan masih memakan waktu yang lama dengan berbagai pertimbangan-pertimbangan yang melibatkan beberapa pihak.

\section{Aliran Sistem Informasi (ASI) Lama}

Untuk lebih mengetahui bagaimana sistem informasi pemberian beasiswa di SMKN 8 Padang, maka penulis melakukan analisa terhadap Aliran Sistem Informasi (ASI) yang sedang berjalan. berikut:

Adapun gambaran dari Aliran Sistem Informasi yang lama adalah sebagai

1. Wali kelas memberikan daftar isian identitas kepada siswa untuk diisi, setelah diisi dikembalikan lagi ke wali kelas.

2. Wali kelas melengkapi data-data siswa dengan beberapa penilaian selama dalam proses belajar mengajar, diantaranya kerajinan, sikap, kedisiplinan, jarak rumah ke sekolah dan penghasilan orang tua dari setiap siswa calon penerima beasiswa. Setelah identitas dan data penilaian calon penerima beasiswa lengkap, lalu diserahkan ke tata usaha.

3. Tata usaha menyerahkan data penilaian calon penerima beasiswa kepada Waka kesiswaan untuk diseleksi.

4. Waka kesiswaan menyeleksi data penilaian calon penerima beasiswa tersebut yang hasilnya berupa data hasil seleksi calon penerima beasiswa dan menyerahkannya ke tata usaha untuk dibuat laporan penerima dana beasiswa sebanyak tiga rangkap.

5. Laporan penerima dana beasiswa tersebut diberikan kepada siswa untuk ditand a tangani dan dikembalikan lagi ke bagian tata usaha. 
6. Tata usaha menyerahkan laporan penerima dana beasiswa yang sudah ditanda tangani siswa kepada Kepala sekolah dan Waka kesiswaan..

\section{Analisa Input}

Data masukan (input) yang dibutuhkan oleh sistem untuk mengolah setiap siswa adalah data siswa, data kriteria, nilai siswa untuk tiap kriteria, nilai bobot kepentingan dari tiap kriteria.

\section{Analisis Output}

Data keluaran (output) dari aplikasi ini adalah menentukan peringkat dari kandidat berdasarkan pada besaran nilai hasil akhir yang dimiliki oleh setiap alternatif sehingga semakin besar nilai hasil akhir yang dimiliki, maka semakin besar pula kesempatan bagi siswa tersebut untuk terpilih sebagai penerima beasiswa, begitu pula sebaliknya. Sehingga memudahkan waka kesiswaan dalam menentukan penerima beasiswa yang layak. Adapun gambaran output yang diperoleh dari SMKN 8 Padang Padang yaitu :

\section{Evaluasi Sistem yang Ada}

Evaluasi yang ada sangat penting dilakukan karena dengan mengevaluasi sistem, akan dapat ditemukan kendala-kendala apa saja yang terjadi pada sistem yang sedang diteliti. Dengan demikian untuk mendesain suatu sistem baru haruslah tepat, agar kesalahan yang mungkin akan terjadi dalam pendesaian sistem baru dapat diperkecil.

\section{Usulan Sistem Baru}

Untuk memperbaiki kekurangan-kekurangan yang terdapat pada sistem lama, maka diusulkan suatu sistem baru. Dimana dalam sistem baru ini akan dilakukan beberapa perubahan terhadap sistem yang lama. Dengan adanya sistem baru yang lebih baik maka diharapkan dapat memperlancar proses pengolahan data dan pembuatan laporan yang lebih cepat dan akurat serta keamanan data lebih terjamin.

\section{Desain Global}

Desain sistem secara global merupakan persiapan dari desain secara terinci dan mengidentifikasi komponen-komponen sistem informasi yang akan didesain secara terinci. Gambaran suatu sistem secara garis besar dapat dirancang dengan beberapa cara yaitu :

1. Aliran Sistem Informasi (ASI) Baru

2. Context Diagram

3. Data Flow Diagram (DFD)

4. Entity Relationship Diagram (ERD)

\section{Aliran Sistem Informasi (ASI) Baru}

Setelah dilakukan penganalisaan terhadap aliran sistem informasi lama maka dengan demikian kita sudah mengetahui tentang proses pengambilan keputusan yang terjadi pada SMKN 8 Padang. Berdasarkan penganalisaan tadi kita dapat temukan pula sejauh mana pada aliran sistem informasi lama ini 
ditemukan kelemahan dalam proses pengambilan keputusan dalam pemberian beasiswa. Penggunaan komputer belum sampai pada proses pengambilan keputusan, karena penggunaan komputer dalam hal ini hanya bersifat pada pembuatan laporan biasa saja.

Adapun aliran sistem yang baru dilihat pada gambar 3.4 berikut ini :

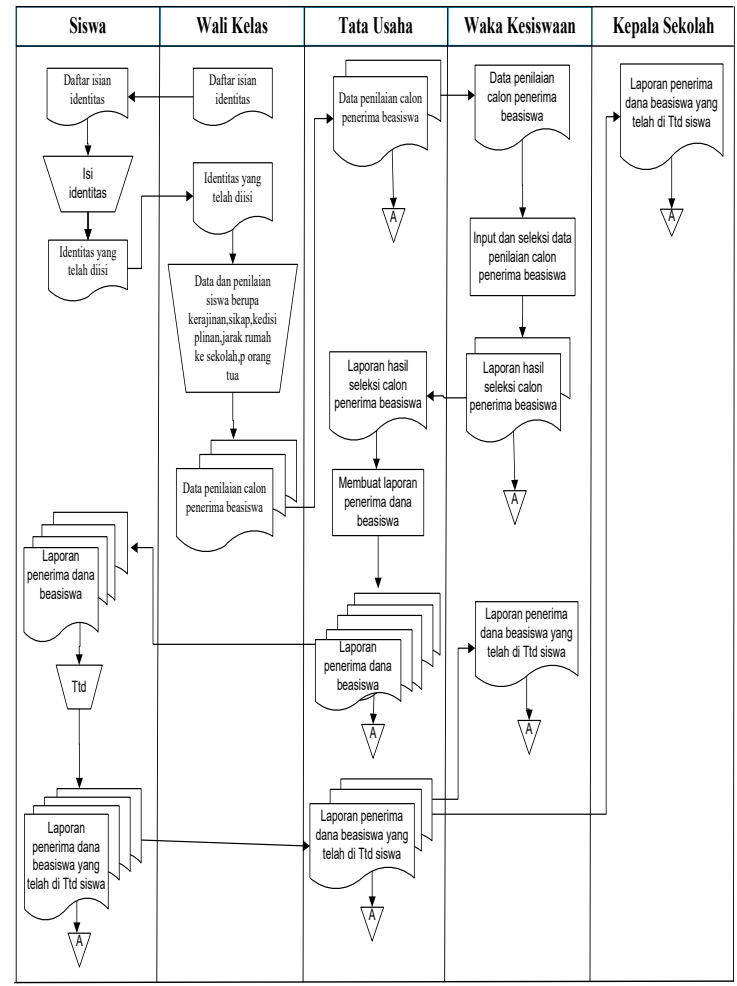

Gambar 1. Aliran Sistem Informasi (ASI) Baru

\section{Contex Diagram}

Contex diagram adalah gambaran umum dari sistem yang ada dalam sebuah organisasi yang memperlihatkan batasan (boundary) sistem, adanya interaksi antara eksternal entity dengan suatu sistem, dan informasi secara umum yang mengalir diantara entity dan sistem. Contex diagram ini merupakan alat bantu yang digunakan dalam menganalisa sistem yang akan dikembangkan. Pada contex diagram ini digambarkan hubungan antara elemen yang membentuk suatu kesatuan.

Dibawah ini adalah gambaran dari contex diagram sistem informasi pemberian beasiswa. 


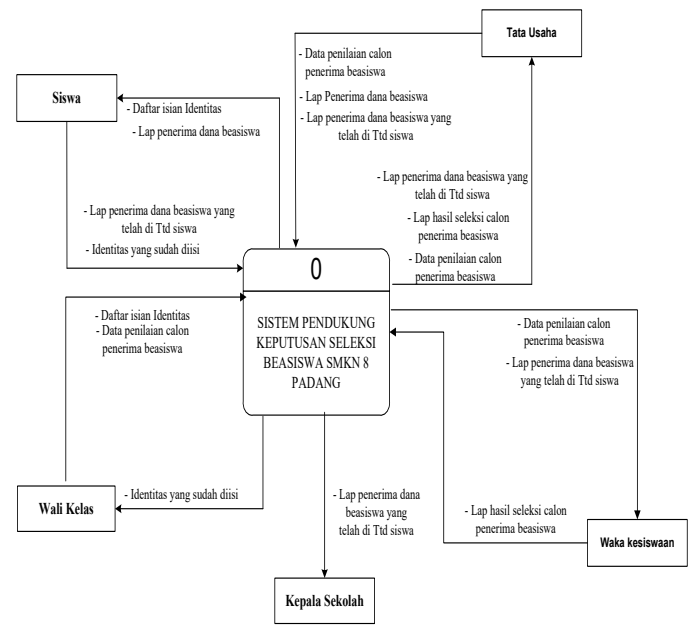

Gambar 2. Contex Diagram

\section{Data Flow Diagram (DFD)}

Data Flow Diagram adalah suatu model dari sistem yang disajikan dalam bentuk logika, dalam menggambarkan logikatersebut menggunakan simbolsimbol diagram arus data. Data flow diagram berfungsi untuk menjabarkan secara rinci rancangan sistem yang baru. Untuk lebih jelasnya dapat dilihat pada gambar 3.6 berikut :

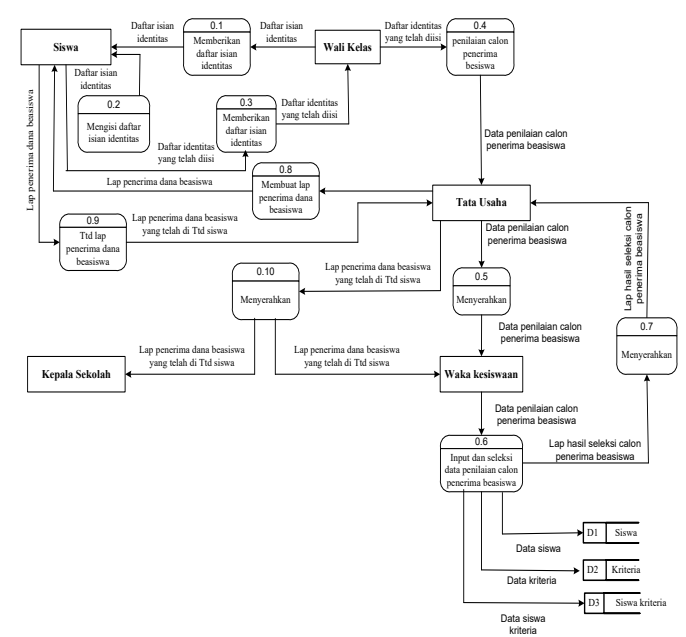

Gambar 3. Data Flow Diagram (DFD) Level 0

\section{Entity Relationship Diagram(ERD)}

Entity Relationship Diagram (ERD) yang disebut juga ER-Diagram merupakan diagram yang menggambarkan hubungan antara sejumlah entity yang berasal dari himpunan entity yang berbeda. 
Pada ERD dapat dilihat hubungan antara satu entity dengan entity yang laiannya, dimana masing- masing entity tersebut mempunyai beberapa atribut dengan satu field kunci serta beberapa foreign key

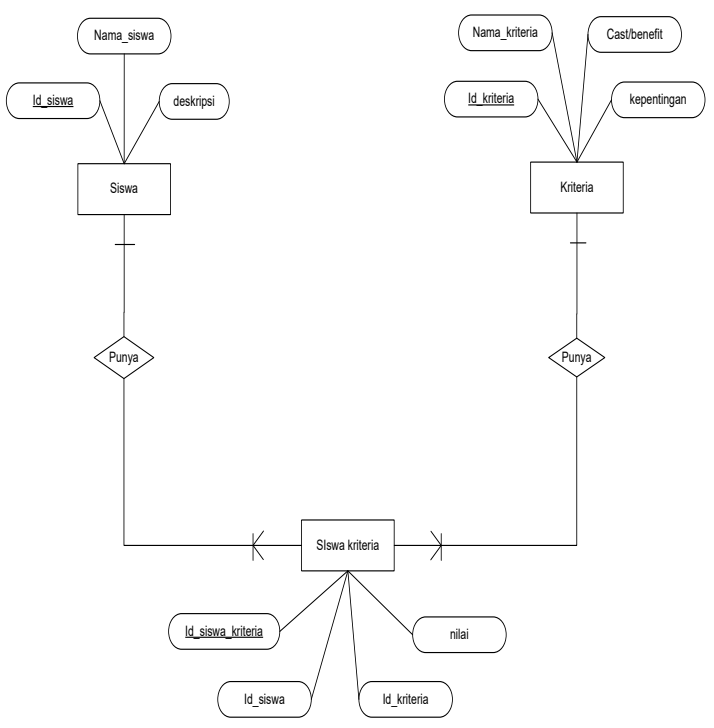

Gambar 4. Entity Relationship Diagram (ERD)

\section{Langkah-Langkah Kerja Weighted Product}

Di dalam merancang suatu perangkat lunak ini diperlukan tahapan-tahapan untuk menyelesaikan permasalahan yang dihadapi dan hal pertama yang harus diketahui adalah bagaimana langkah pembuatan Sistem Pendukung Keputusan (SPK) dengan menerapkan metode Weighted Product (WP) menggunakan bahasa pemrograman Visual Basic Net, sehingga dapat memudahkan pemakai dalam menyeleksi calon penerima beasiswa tersebut dalam menganalisa dan mengambil keputusan yang cepat dan tepat dari hasil yang telah diolah.

Adapun langkah-langkah dalam menggunakan metode Weighted Product tersebut yaitu:

1. Mengalikan seluruh atribut bagi sebuah siswa dengan bobot sebagai pangkat positif untuk atribut manfaat dan bobot berfungsi sebagai pangkat negatif pada atribut biaya.

2. Hasil perkalian dijumlahkan untuk menghasilkan nilai pada setiap siswa.

3. Mencari nilai siswa dengan melakukan langkah yang sama seperti pada langkah satu, hanya saja menggunakan nilai tertinggi untuk setiap atribut tertinggi untuk setiap atribut manfaat dan nilai terendah untuk atribut biaya.

4. Membagi nilai $\mathrm{V}$ bagi setiap siswa dengan nilai standar $\left(\mathrm{V}\left(\mathrm{A}^{*}\right)\right)$ yang menghasilkan R.

5. Ditemukan urutan siswa terbaik yang akan menjadi keputusan.

\section{Rancangan Proses}


Keluaran yang dihasilkan dari penelitian ini adalah sebuah siswa yang memiliki nilai tertinggi dibandingkan dengan siswa nilai yang lain. Pada penelitian ini hasil keluarannya diambil dari urutan siswa tertinggi ke siswa terendah.Hasil akhir yang dikeluarkan oleh program nanti berasal dari nilai setiap kriteria, karena dalam setiap kriteria memiliki nilai yang berbeda-beda. Siswa yang dimaksud adalah

Adapun proses dan kriteria penilaian yang diperhitungkan dalam menyeleksi calon penerima beasiswa pada SMKN 8 Padang menggunakan metode Weighted Product (WP) adalah sebagai berikut :

Tabel 1. Kriteria Pertimbangan

\begin{tabular}{|l|l|}
\hline Kriteria & Keterangan \\
\hline C1 & Kerajinan \\
\hline C2 & Sikap \\
\hline C3 & Kedisiplinan \\
\hline C4 & $\begin{array}{l}\text { Jarak rumah ke sekolah } \\
\text { Km) }\end{array}$ \\
\hline C5 & Penghasilan orang tua \\
\hline
\end{tabular}

Dalam metode penelitian ini ada bobot kriteria yang dibutuhkan. Adapun tingkat kepentingan yang nantinya akan dibobotkan di tiap kriteria adalah sebagai berikut :

Tabel 2. Tingkat Kepentingan Dari Tiap Kriteria

\begin{tabular}{|l|c|}
\hline Kepentingan & Nilai \\
\hline Sangat rendah & 1 \\
\hline Rendah & 2 \\
\hline Cukup & 3 \\
\hline Tinggi & 4 \\
\hline Sangat tinggi & 5 \\
\hline
\end{tabular}

Selanjutnya pengambil keputusan memberikan bobot preferensi untuk masing-masing kriteria sebagai $\mathrm{W}=(5,5,5,4,5)$.

Tabel 3. Pemberian Bobot Preferensi Dari Tiap Kriteria

\begin{tabular}{|l|l|l|}
\hline Kriteria & Keterangan & Bobot \\
\hline C1 & Kerajinan & 5 \\
\hline C2 & Sikap & 5 \\
\hline
\end{tabular}




\begin{tabular}{|l|l|l|} 
C3 & Kedisiplinan & 5 \\
\hline C4 & $\begin{array}{l}\text { Jarak rumah ke sekolah } \\
(\mathrm{Km})\end{array}$ & 4 \\
\hline C5 & Penghasilan orang tua & 5 \\
\hline
\end{tabular}

Berdasarkan data yang telah diperoleh dari SMKN 8 Padang, dapat kita bentuk sebuah rating kecocokan dari setiap siswa pada setiap nilai kriteria ini, yaitu sebagai berikut:

Tabel 4 Rating Kecocokan Dari Setiap Siswa Pada Kriteria

\begin{tabular}{|l|l|l|l|l|l|}
\hline \multirow{2}{*}{$\begin{array}{l}\text { Sisw } \\
\text { a }\end{array}$} & \multicolumn{5}{|c|}{ Nilai Kriteria } \\
\cline { 2 - 6 } & $\mathrm{C} 1$ & $\mathrm{C} 2$ & $\mathrm{C} 3$ & $\mathrm{C} 4$ & $\mathrm{C} 5$ \\
\hline S1 & 80 & 75 & 83 & 1 & $\begin{array}{l}170000 \\
0\end{array}$ \\
\hline S2 & 80 & 85 & 75 & 3 & $\begin{array}{l}125000 \\
0\end{array}$ \\
\hline
\end{tabular}

Nilai dari setiap siswa pada kriteria terlampir S3 sampai dengan S30

Kategori untuk setiap kriteria adalah sebagai berikut :

a. Kriteria C1 (Kerajinan), C2 (Sikap), C3 (Kedisiplinan), C4 (Jarak rumah ke sekolah) adalah atribut keuntungan.

b. Kriteria C5 (Penghasilan orang rua) adalah atribut biaya.

Sebelumnya dilakukan perbaikan bobot terlebih dahulu sehingga $\sum \mathrm{W}=1$, maka didapat perhitungan sebagai berikut:

$$
\begin{aligned}
& \mathrm{W}_{1}=\frac{5}{5+5+5+4+5}=\frac{5}{24}=0.21 \\
& \mathrm{~W}_{2}=\frac{5}{5+5+5+4+5}=\frac{5}{24}=0.21 \\
& \mathrm{~W}_{3}=\frac{5}{5+5+5+4+5}=\frac{5}{24}=0.21 \\
& \mathrm{~W}_{4}=\frac{4}{5+5+5+4+5}=\frac{4}{24}=0.16 \\
& \mathrm{~W}_{5}=\frac{5}{5+5+5+4+5}=\frac{5}{24}=0.21
\end{aligned}
$$

Kemudian vektor S dihitung dengan berdasarkan persamaan :

$$
S i=\prod_{j=1}^{n} x_{i j}^{w j} \quad \text { dengan } i=1,2, \ldots, m
$$

Dimana $\sum W j=1 \mathrm{Wj}$ adalah pangkat bernilai positif untuk atribut keuntungan dan bernilai negatif untuk atribut biaya, kemudian Vektor S dapat dihitung sebagai berikut :

$$
\begin{aligned}
& S_{1}=\left(80^{0.21}\right)\left(75^{0.21}\right)\left(83^{0.21}\right)\left(1^{0.16}\right)\left(1700000^{-0.21}\right)=0.7743 \\
& S_{2}=\left(80^{0.21}\right)\left(85^{0.21}\right)\left(75^{0.21}\right)\left(3^{0.16}\right)\left(1250000^{-0.21}\right)=0.9963 \\
& \text { Vektor S dihitung terlampir S3 sampai dengan S30. } \\
& \text { Nilai vector V yang digunakan untuk perangkingan dengan dihitung } \\
& \text { berdasarkan: }
\end{aligned}
$$


Sebagai berikut :

$$
V i=\frac{\prod_{j=1}^{n} x_{w j w_{j}}}{\prod_{j=1}^{n}\left(x_{j}^{w}\right) w j} \quad \text { dengan } i=1,2, \ldots, m
$$

$$
\begin{aligned}
V_{1}=0.7743 / & (0.7743+0.9963+1.0210+1.0766+0.9568+1.0525 \\
& +1.1517+0.9921+0.9255+0.8373+0.9072+0.9243 \\
& +1.0494+0.9032+0.8729+1.0523+1.1046+0.7839 \\
& +0.9156+1.1394+1.0478+0.9679+1.1915+1.0297 \\
& +1.1489+1.1159+1.0568+1.0089+1.1415+1.1499) \\
& =0.7743 / 30.2957=0.0255 \\
V_{2}=0.9963 / & (0.7743+0.9963+1.0210+1.0766+0.9568+1.0525 \\
& +1.1517+0.9921+0.9255+0.8373+0.9072+0.9243 \\
& +1.0494+0.9032+0.8729+1.0523+1.1046+0.7839 \\
& +0.9156+1.1394+1.0478+0.9679+1.1915+1.0297 \\
& +1.1489+1.1159+1.0568+1.0089+1.1415+1.1499) \\
& =0.9963 / 30.2957=0.0328
\end{aligned}
$$

Nilai vector V untuk perengkingan dihitung terlampir V3 sampai dengan V30.

Dari perhitungan Weighted Product tersebut diperoleh hasil sebagai berikut:

Tabel 5. Hasil perhitungan Weighted Product

\begin{tabular}{|l|l|l|}
\hline Siswa & $\begin{array}{l}\text { Nilai } \\
\text { Vektor S }\end{array}$ & $\begin{array}{l}\text { Nilai } \\
\text { Vektor V }\end{array}$ \\
\hline S1 & 0.7743 & 0.0255 \\
\hline S2 & 0.9963 & 0.0328 \\
\hline
\end{tabular}

Hasil perhitungan ini terlampir S3 sampai dengan S30.

Langkah terakhir adalah proses hasil perangkingan dan seleksi keputusan. Hasilnya diperoleh :

Tabel 6. Hasil Perengkingan Dan Seleksi Keputusan

\begin{tabular}{|l|l|l|l|l|}
\hline No & Siswa & Nama & Nilai & Keputusan \\
\hline 1 & S23 & $\begin{array}{l}\text { Hamidah } \\
\text { Hamid }\end{array}$ & 0.0393 & $\begin{array}{l}\text { Layak } \\
\text { Menerima }\end{array}$ \\
\hline 2 & S7 & $\begin{array}{l}\text { David } \\
\text { Syofyan }\end{array}$ & 0.0380 & $\begin{array}{l}\text { Layak } \\
\text { Menerima }\end{array}$ \\
\hline
\end{tabular}

Hasil perengkingan dan seleksi keputusan

No 3 sampai dengan No 30. Sehingga siswa S23 (Hamidah Hamid) adalah siswa yang terpilih sebagai nilai siswa tertinggi.

\section{Flowchart}

Logika program menunjukkan aliran data pada program yang akan dirancang. Dengan adanya logika maka user lebih mudah memahami dan tepat mengoperasikan sistem yang dibuat dalam logika program. 
Berikut ini adalah flowchart dari sitem pendukung keputusan untuk seleksi beasiswa pada SMKN 8 Padang:

1. Flowchart Menu Utama

Dalam menu utama ini terdapat bagian-bagian yang akan di proses yaitu sebagai sub menu file, sub menu input data sub menu analisa, sub menu laporan dan sub menu penganturan.

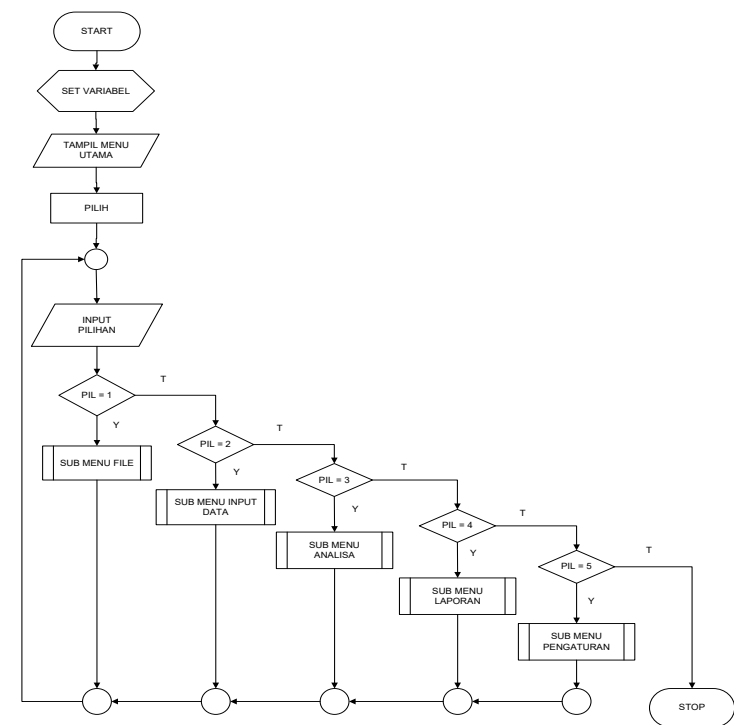

Gambar 5. Flowchart Menu Utama

2 Flowchart Input User

Menginputkan data admin,setelah masuk inputkan kode dan ketemu data user sebagai admin lanjut simpan data user. Ketika mengganti nama usernya maka bisa di ubah data user dan simpan, apabila salah menginputkan maka melakukan proses hapus, inputkan kembali setelah itu simpan dan keluar.

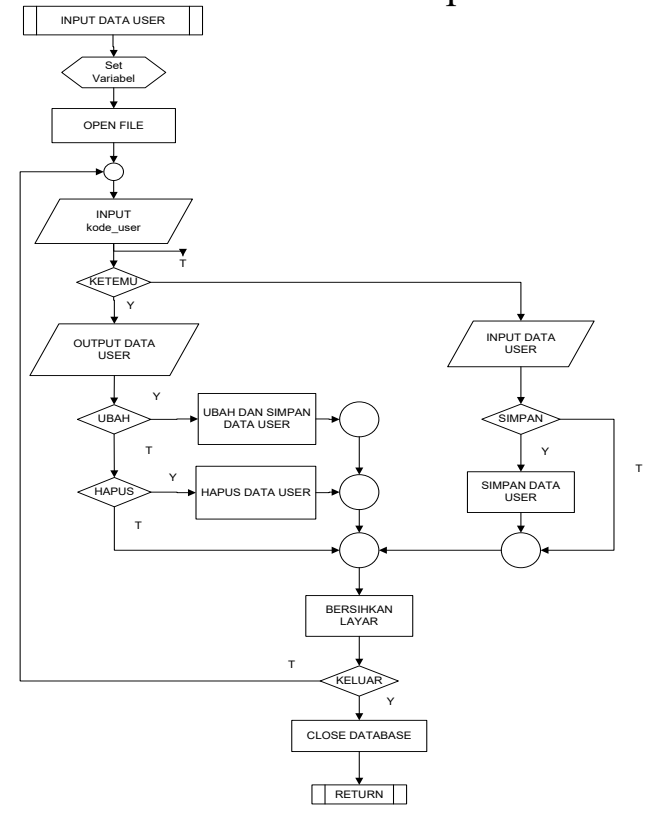




\section{$3 \quad$ Flowchart Input Kriteria}

Admin Melakukan input data kriteria dimulai dari mengisi nama kriteria, setelah di isi data kriteria tersebut lalu disimpan dan data kriteia tersebut bisa diubah apabila salah menginputkan lalu simpan. Ketika melakukan penginputan data yang salah maka bisa melakukan penghapusan dan keluar dari proses. Data tersebut sudah bisa menghasilkan laporan dari hasil penginputan kriteria.

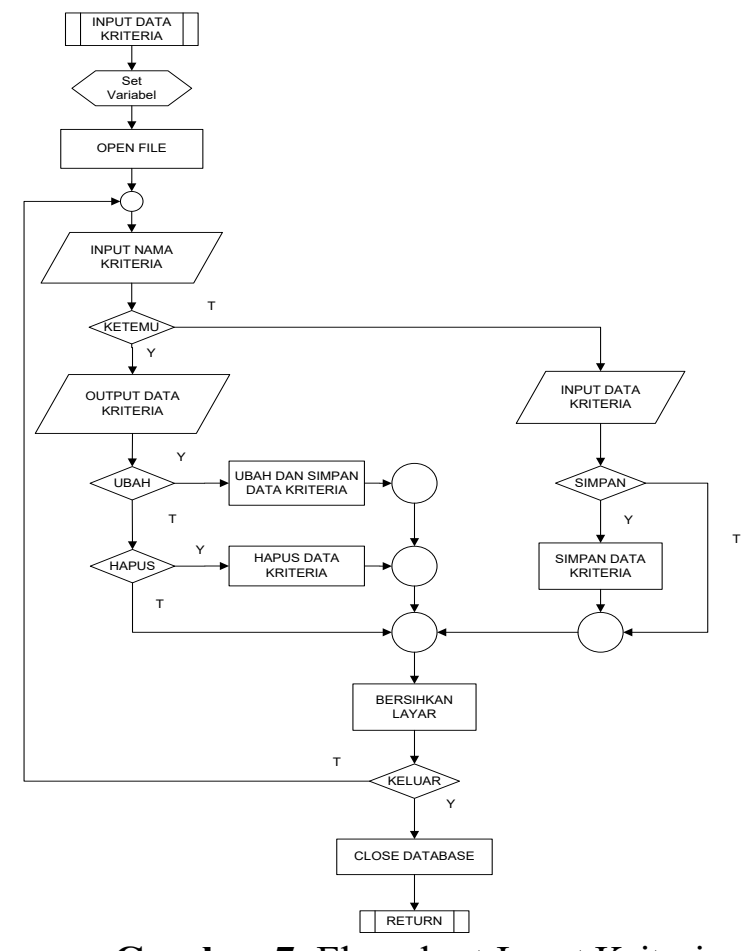

Gambar 7. Flowchart Input Kriteria

$4 \quad$ Flowchart Input Siswa

Admin Melakukan input data siswa dimulai dari mengisi nama siswa, setelah di isi data siswa tersebut lalu disimpan dan data siswa tersebut bisa diubah apabila salah menginputkan lalu simpan. Ketika melakukan penginputan data yang salah maka bisa melakukan penghapusan dan keluar dari proses. Data tersebut sudah bisa menghasilkan laporan dari hasil input siswa. 


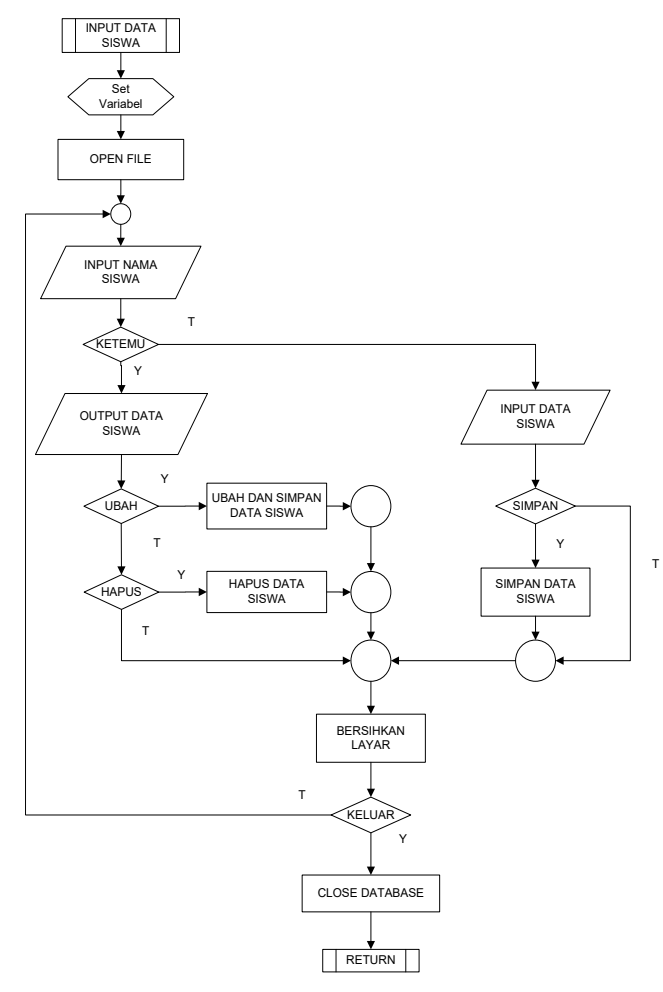

Gambar 8. Flowchart Input Siswa

\section{$5 \quad$ Flowchart Siswa Kriteria}

Admin Melakukan input data siswa kriteria dimulai dari mengisi nama siswa kriteria, setelah di isi data siswa kriteria tersebut lalu disimpan dan data siswa kriteria tersebut bisa diubah apabila salah menginputkan lalu simpan. Ketika melakukan penginputan data yang salah maka bisa melakukan penghapusan dan keluar dari proses.

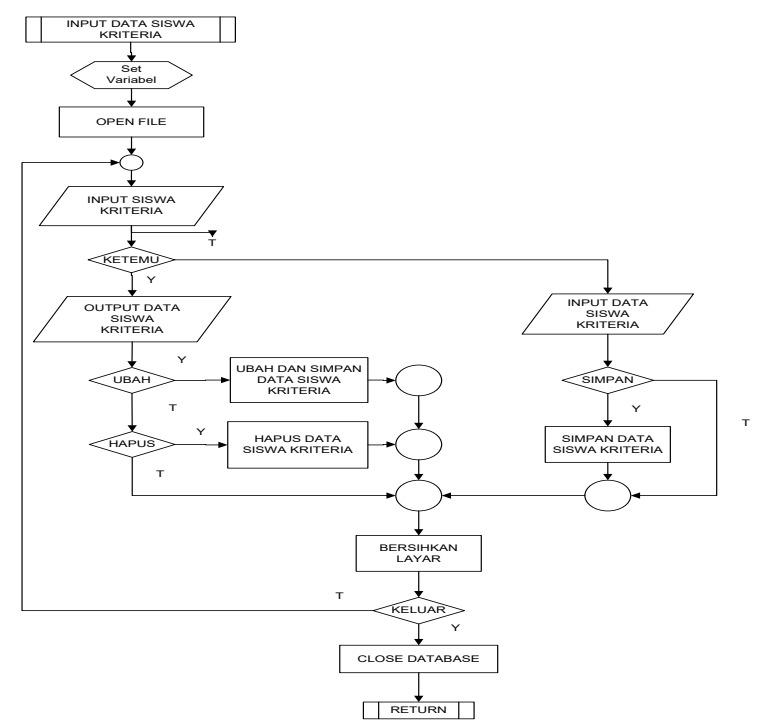

Gambar 9. Flowchart Input Siswa Kriteria 
6 Flowchart Hasil Analisa Sistem Pendukung Keputusan (SPK)

Admin menuju menu utama dan memilih analisa, di dalam analisa tersebut terdapat perhitungan yang telah di proses dari data kriteria, data siswa dan data siswa kriteria.

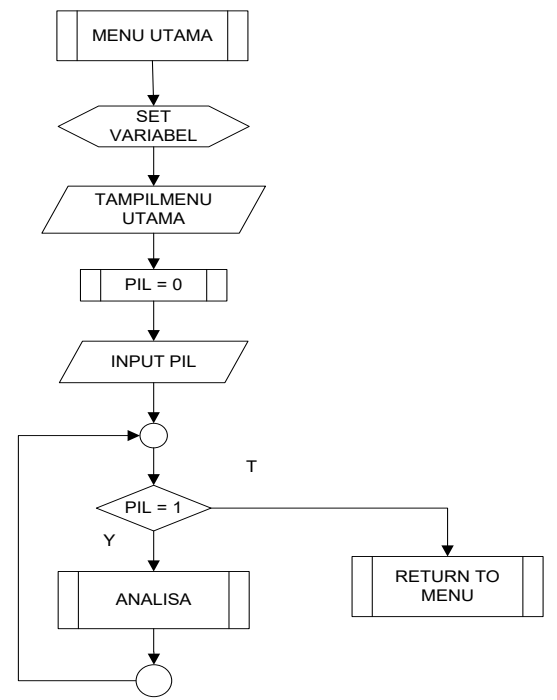

Gambar 10. Flowchart Hasil Analisa SPK

$7 \quad$ Flowchart Laporan Hasil Perhitungan WP

Admin masuk ke sub menu laporan perhitungan untuk melakukan cetak laporan, setelahmelakukan cetak laporan perhitungan lalu tutup dan kembali ke menu utama

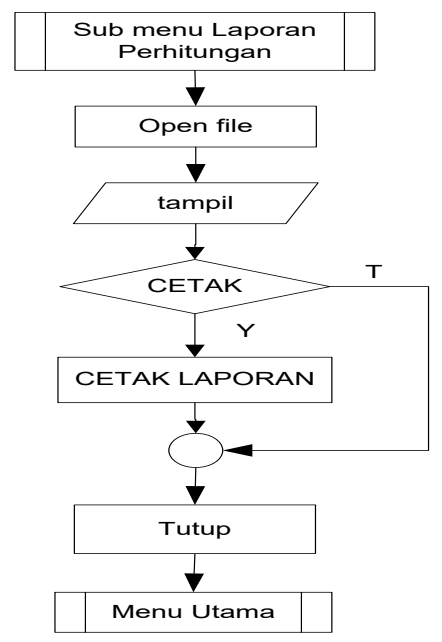

Gambar 11. Flowchart Laporan Hasil Perhitungan

8 Flowchart Laporan Keputusan Seleksi Beasiswa 
Admin masuk ke sub menu laporan keputusan untuk melakukan cetak laporan, setelah melakukan cetak laporan keputusan lalu tutup dan kembali ke menu utama.

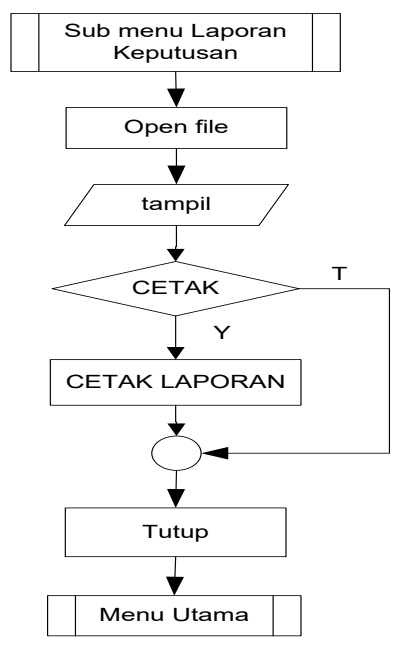

Gambar 12. Flowchart Laporan Keputusan seleksi beasisa

\section{HASIL DAN PEMBAHASAN}

\section{Hasil}

Hasil dari penulisan skripsi ini yaitu suatu pembahasan dan sebuah aplikasi pendukung keputusan untuk menentukan penerima beasiswa pada SMKN 8 Padang. Pada bab ini akan dijelaskan bagaimana tampilan input dan output dari aplikasi yang telah dibuat.

\section{Implementasi Sistem}

Tahap pengujian terhadap sistem dilakukan untuk mengetahui sejauh mana sistem yang dirancang dapat meminimalkan masalah, serta untuk mengetahui hubungan antar komponen system.

\section{Form Menu Utama}

Form menu utama adalah antar muka (interface) yang digunakan sebagai form induk atau form utama. Tampilan form menu utama menampilkan menu yang terdiri dari menu file, menu input data, menu analisa, menu laporan serta menu pengaturan. Masing-masing dari menu tersebut juga memiliki sub menu tersendiri. Form menu utama ini akan selalu ditampilkan saat program dijalankan. Untuk lebih jelasnya dapat dilihat pada gambar 13 sebagai berikut. 
Juthal Ilmiah Metadata, ISSN: 2723-7737, Vol.2 No.3 Edisi September 2020

Published: 11-09-2020, Pages: 232-255

DOI: https://doi.org/10.10101/metadata.v2i3

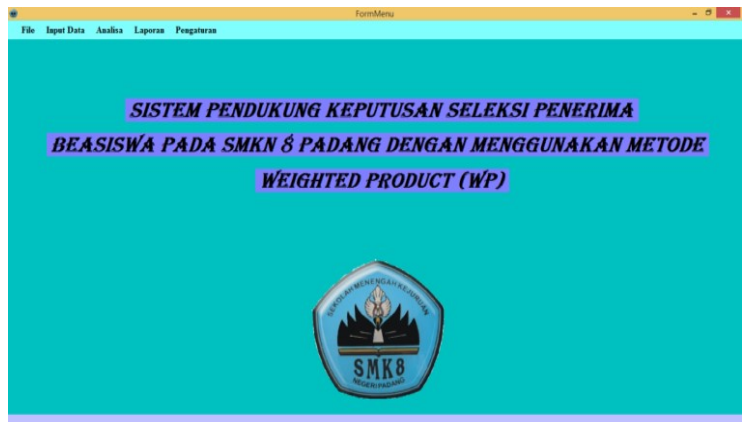

Gambar 13. Form Menu Utama

\section{Form Menu File}

Menu file terdiri dari sub menu login dan sub menu keluar. Untuk lebih jelasnya dapat dilihat pada gambar 14 :

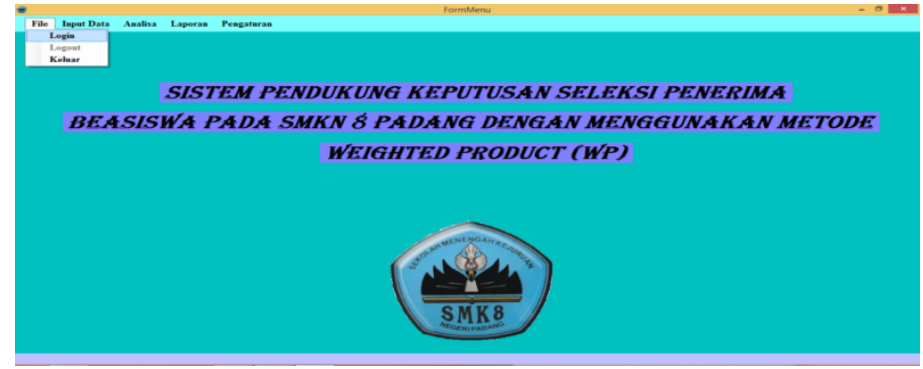

Gambar 14. Form Menu File

\section{Form Sub Menu Login}

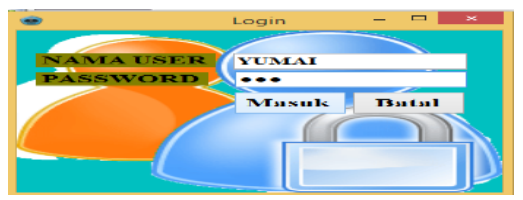

Gambar 15. Form Sub Menu Login

\section{Form Menu Input Data}

Menu input data terdiri dari sub menu data kriteria, sub menu data siswa, dan sub menu data siswa kriteria. Untuk lebih jelasnya dapat dilihat pada gambar 16.

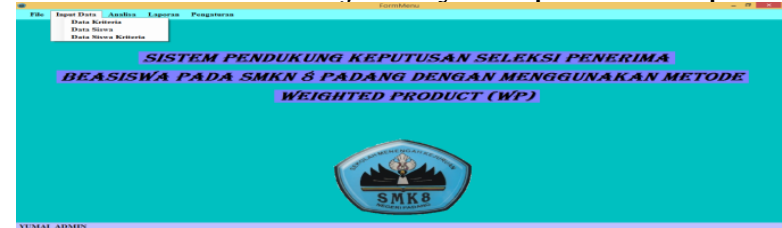

Gambar 16. Form Menu Input Data 


\section{Form Sub Menu Data Kriteria}

Form sub menu data kriteria digunakan untuk menyimpan data kriteria penilaian ke database. Seperti terlihat pada gambar 17.

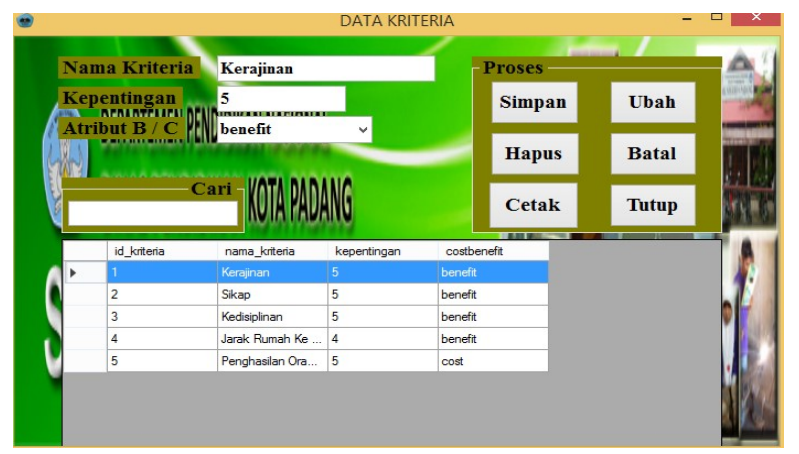

Gambar 17. Form Sub Menu Data Kriteria

\section{Form Sub Menu Data Siswa}

Form sub menu data siswa digunakan untuk menyimpan data siswa atau calon penerima beasiswa ke database. Seperti terlihat pada gambar 18:

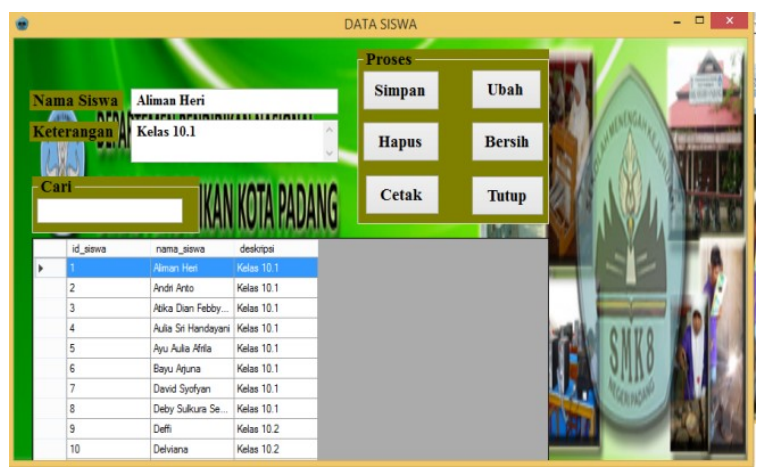

\section{Gambar 18. Form Sub Menu Data Siswa}

\section{Form Sub Menu Data Siswa Kriteria}

Form sub menu data siswa kriteria digunakan untuk menyimpan data penillaian calon penerima beasiswa berdasarkan kriteria yang telah ditentukan ke database. Seperti terlihat pada gambar 19: 


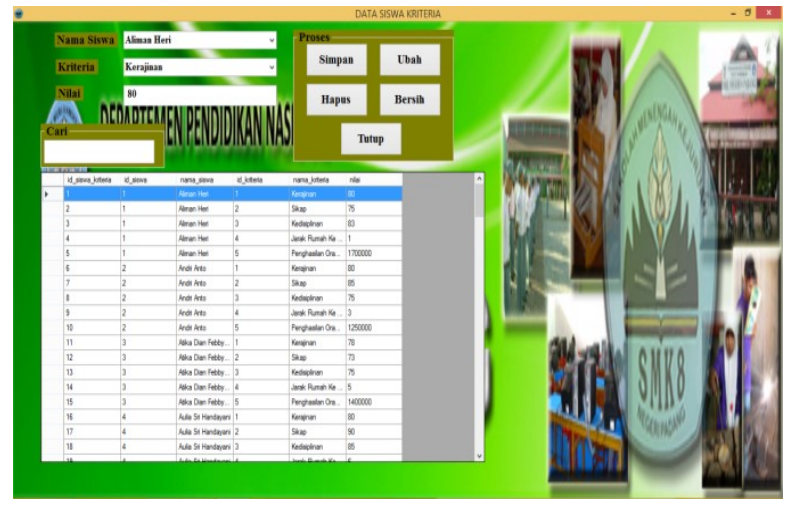

Gambar 19. Form Sub Menu Data Siswa Kriteria

\section{Form Menu Analisa}

Form menu analisa menunjukkan penilaian dan hasil perhitungan serta keputusan. Untuk lebih jelasnya dapat dilihat pada gambar 20:

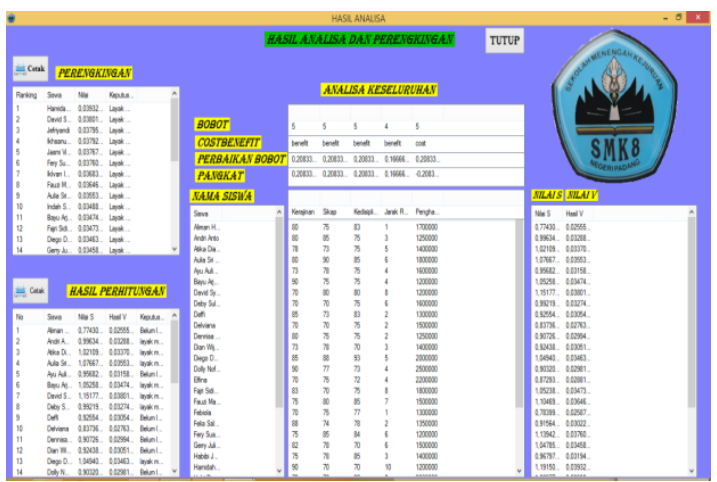

Gambar 20. Form Analisa

\section{Form Menu Laporan}

Menu laporan terdiri dari sub menu siswa, sub menu kriteria, sub menu keputusan, dan sub menu perhitungan. Seperti terlihat pada gambar 21:

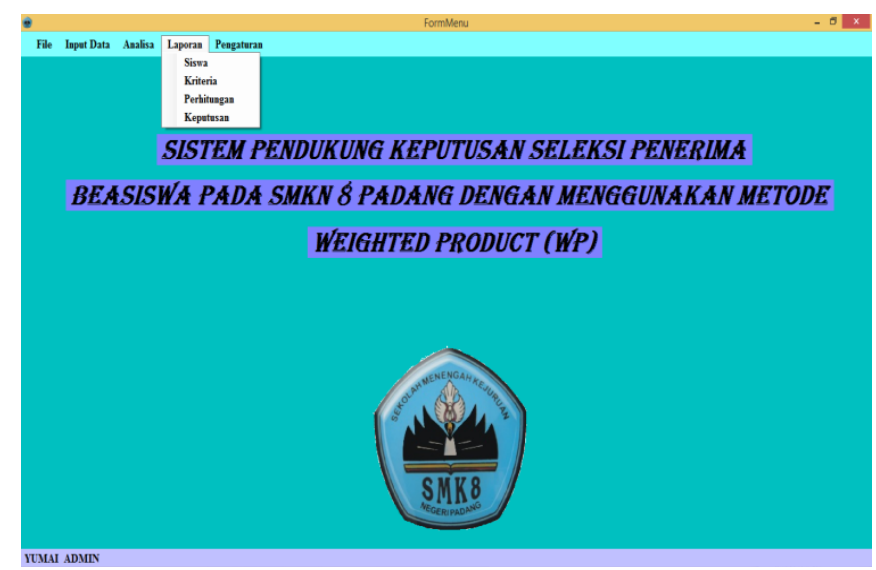

Gambar 21. Form Menu Laporan 


\section{Laporan Siswa}

Untuk menentukan calon penerima beasiswa ini dilakukan daftar siswa yang ingin dimasukan ke data untuk di seleksi nantinya dan menentukan mana yang akan berhak menerimanya.

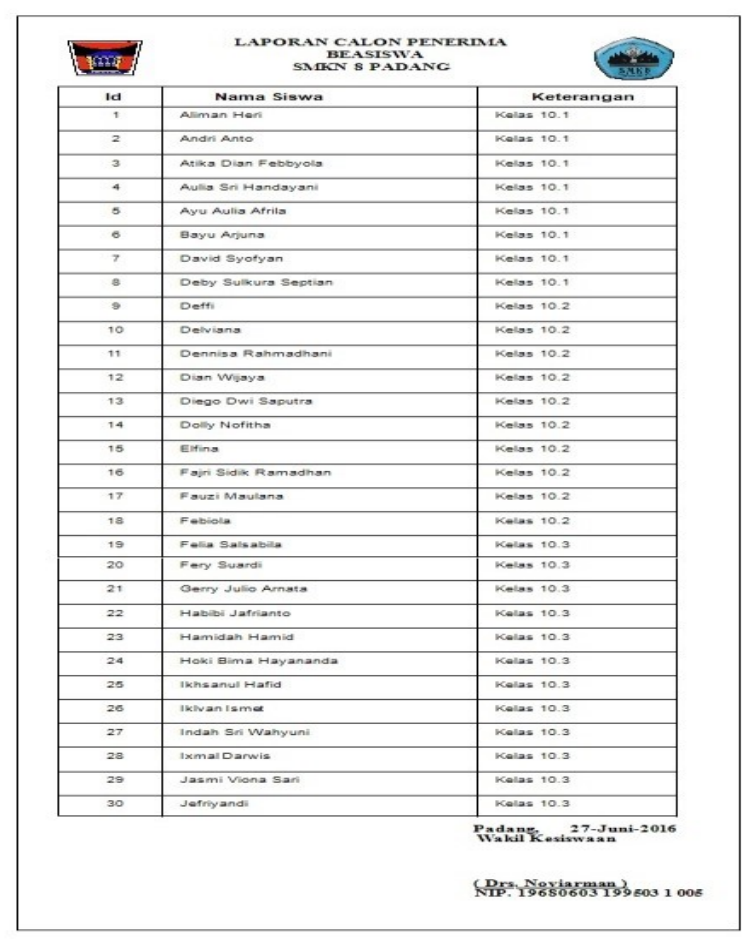

Gambar 22. Laporan Siswa

\section{Laporan Kriteria}

Dalam kriteria penilaian untuk penyeleksian beasiswa ini dapat membantu dan memudahkan dalam menentukan pemilihan beasiswa.

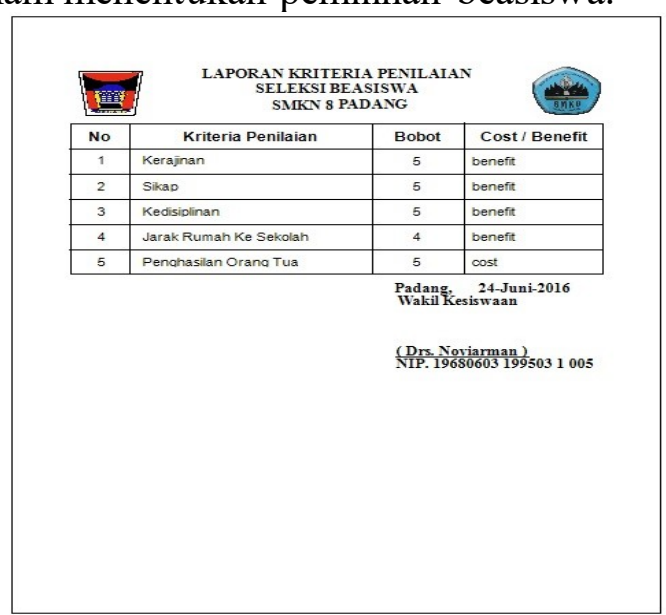

Gambar 23. Laporan Kriteria 
Juthal Ilmiah Metadata, ISSN: 2723-7737, Vol.2 No.3 Edisi September 2020

Published: 11-09-2020, Pages: 232-255

DOI: https://doi.org/10.10101/metadata.v2i3

\section{Laporan Perhitungan}

Dalam melakukan hasil perhitungan seleksi beasiswa yang telah di proses dan menentukan mana yang belum layak ataupun layak menerima beasiswa, telah bisa di lihat dalam laporan tersebut.

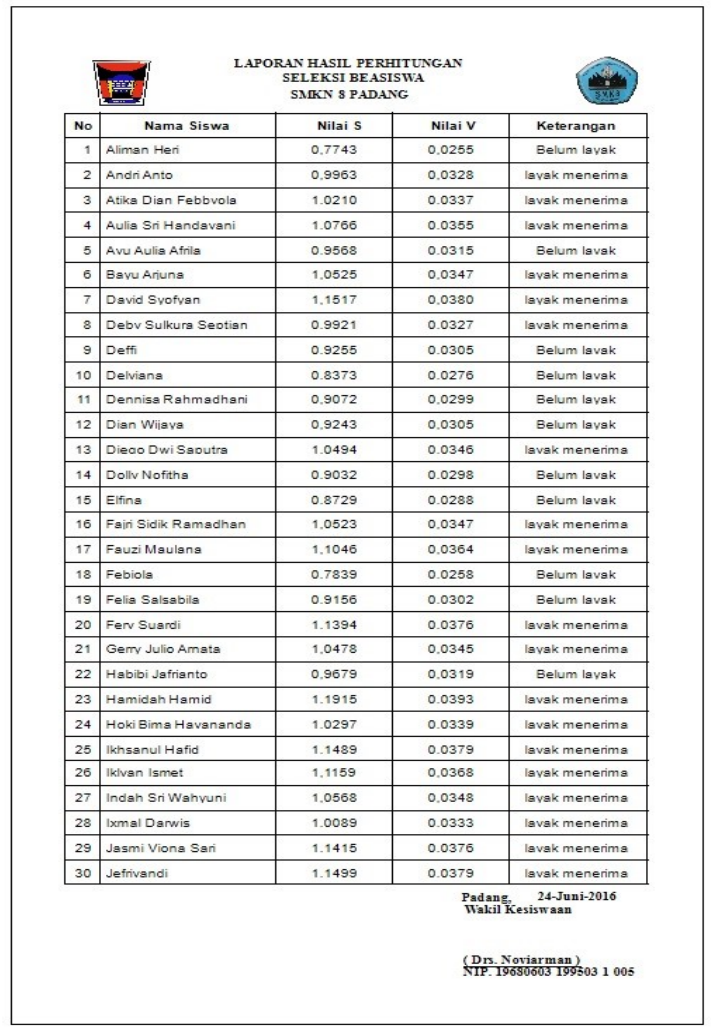

Gambar 24. Laporan Perhitungan

\section{Laporan Keputusan}

Setelah melakukan hasil perhitungan yang telah diproses sebelumnya, laporan ini sudah bisa di ambil keputusan sebagaimana mestinya nama-nama siswa yang berhak menerima beasiswa pada SMKN 8 Padang. 


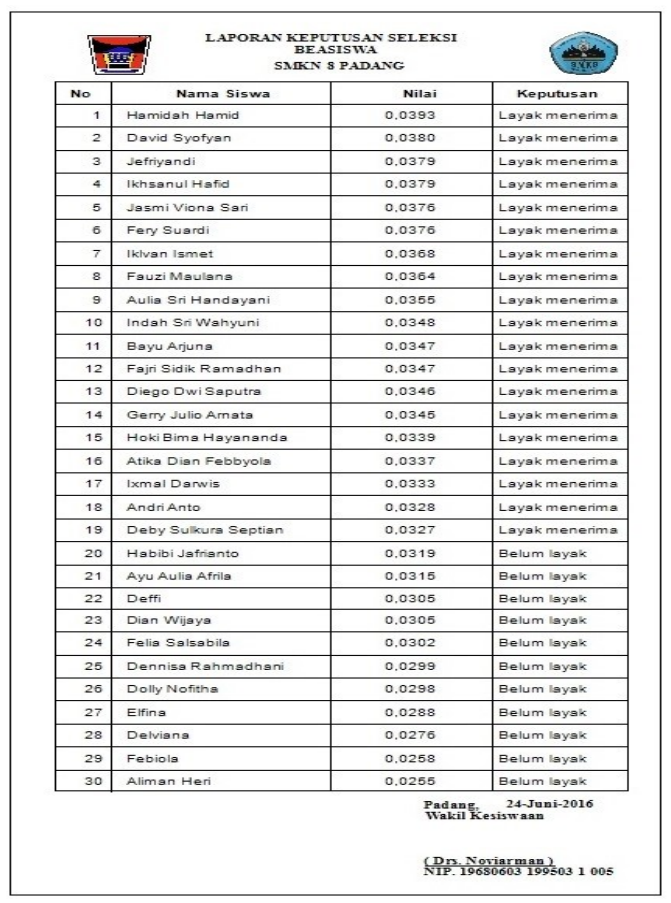

Gambar 25. Laporan Keputusan

Setelah melakukan pengujian sistem, maka dapat disimpulkan bahwa aplikasi Sistem Pendukung Keputusan dengan metode WP (Weighted Product) ini berjalan sebagaimana mestinya dan sesuai dengan perancangan yang telah dibuat.

\section{Form Menu Pengaturan}

Menu pengaturan terdiri dari sub menu ganti password dan sub menu user. Untuk lebih jelasnya dapat dilihat pada gambar 26.

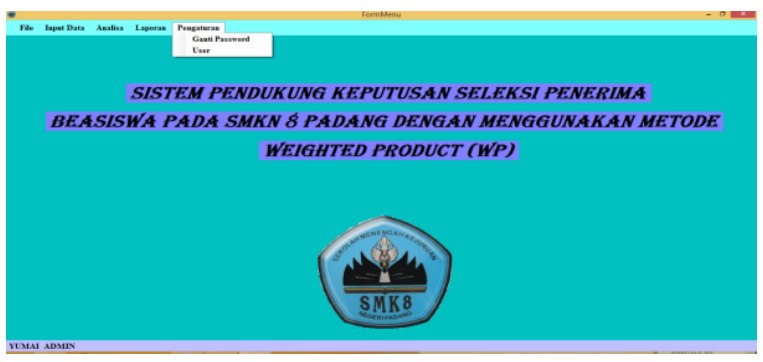

Gambar 26. Form Menu Pengaturan

\section{Form Sub Menu Ganti Password}

Form ganti password berguna untuk keaaman bagi user, apabila password si user diketahui oleh orang lain, maka user tersebut biasa menggantinya 


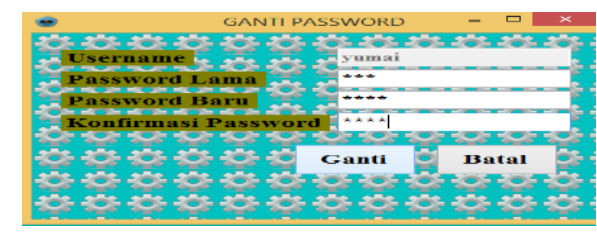

Gambar 27. Form Sub Menu Ganti Password

\section{Form Sub Menu User}

Form user berguna bagi admin untuk biasa menambahkan, merubah, bahkan menghapus data user. Seperti terlihat pada gambar 28:

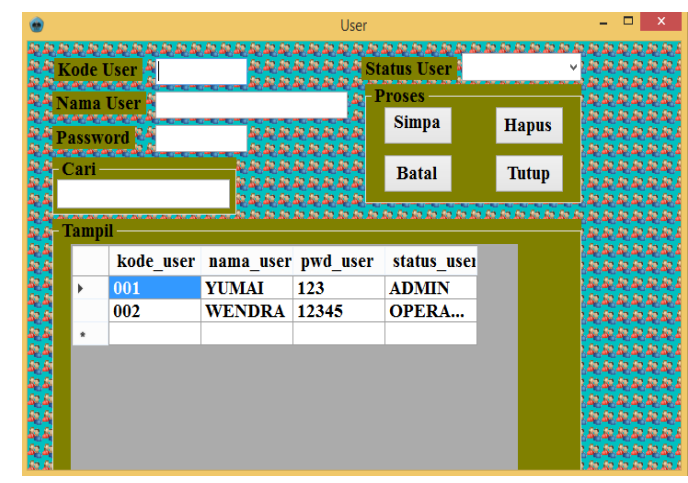

Gambar 28. Form Sub Menu User

\section{KESIMPULAN}

Perancangan sistem baru akan banyak mendatangkan kemudahan dalam melakukan pengolahan data dan penyajian informasi, tapi dalam menetapkan sistem baru ini akan mendapatkan kendala, dan untuk itu perlu dilakukan pengadaptasian kepada pihak sekolah, yang nantinya akan dapat membantu dalam efisiensi dan efektifitas pekerjaan. Adapun kesimpulan yang dapat diambil dari pembahasan skripsi ini adalah: Penerima beasiswa pada SMKN 8 Padang dapat ditentukan menggunakan aplikasi system pendukung keputusan yang telah dirancang. Kriteria penilaian dalam seleksi penerima beasiswa pada SMKN 8 Padang yaitu berupa nilai kerajinan, sikap, kedisiplinan, jarak rumah ke sekolah $(\mathrm{Km})$ dan penghasilan orang tua dengan tingkat kepentingan masing-masing kriteria penilaian tersebut telah ditentukan sebelumnya. Aplikasi system pendukung keputusan ini dapat menyleksi calon penerima beasiswa pada SMKN 8 Padang, Aplikasi ini dirancang menggunakan bahasa pemograman Visual Basic Net dengan database MySQL. Penerapan metode Weighted Product (WP) dapat efektif dan efisien

\section{DAFTAR PUSTAKA}

Darmayuda, Ketut . 2014. Aplikasi Basis Data dengan Visual Basic. NET. Bandung: Informatika Bandung. 
Enterprise, Jubilee. 2014. MySQL Untuk Pemula. Jakarta: PT Elex Media Komputindo.

Gunawan, Kesuma Prananingrum dan Ririn dan Wigati Restu Ruwilin. 2013. "Pengembangan Sistem Penunjang Keputusan Penentuan Pemberian Beasiswa Tingkat Sekolah”. ISSN Vol 14, No 2, Oktober 2013.

Heryanto, Imam. 2012. "Membuat Database Dengan Microsoft Access". Bandung: Informatika Bandung.

Hirin. 2011. "Belajar Tuntas VB. NET 2010. Jakarta: PT. Prestasi Pustakaraya Jaya,putra. 2013. "Sistem Pendukung Keputusan Penentuan Bonus Karyawan Menggunakan Metode Weighted Product (WP)”. ISSN Vo V, No 2, Desember 2013.

Pratama, I Putu Agus Eka. 2014. Sistem Informasi dan Implementasinya. Bandung: Informatika Bandung.

Pratama, Ramadhani Noor dan Faslah Ronny. 2014. "Implementasi Metode Weighted Product Terhadap Sistem Pendukung Keputusan Seleksi Usulan Pengadaan Dari Puskesmas Di Dinas Kesehatan Kota BanjarBaru”. ISSN Vol 2, No 2, Oktober 2014

Putra Apriansyah dan Hardiyanti Yunika Dinna. 2011. "Penentuan Penerimaaan Beasiswa Dengan Menggunakan Fuzzy Multiple Atribute Decission Makin”. ISSN Vo.3, No.1 April 2011.

Rani, Sasika. 2014. "Sistem Pendukung Keputusan Pemilihan Sepeda Motor Berbasis Web Dengan Metode Weighthed Product'. ISSN Vol Vil, No 3, Agustus 2014.

Sutabri, Tata. 2012. Analisis Sistem Informasi. Jakarta: CV ANDI OFFSET

Togatorop, Fernandex dan Arnando. 2015. "Penerapan Metode Weighted Product (WP) Dalam Sistem Pendukung Keputusan Penilaian Kinerja Karyawan Pada PT. Johan Sentosa Kab.Kampar". ISSN Vol V, No 2, Januari 2015.

RN Ichsan, E Surianta, L Nasution, 2020. Pengaruh Disiplin Kerja Terhadap Kinerja Pegawai Negeri Sipil (PNS) Dilingkungan Ajudan Jenderal Daerah Militer (AJENDAM) -I Bukit Barisan Medan, Jurnal Darma Agung 28(2), 187-210. 
Lukman Nasution, Reza Nurul Ichsan, Mega Arisia Dewi, Buyung Perdana Surya, Efriyani Sumastuti, 2020. Emerging Supply and Demand as a Mix of Social, Economic, and Psychological Factors, Journal of critical reviews JCR.2020; 7 (17) : 421-424.

Jonner Lumban Gaol, Reza Nurul Ichsan, Lamminar Hutabart, 2020. The effect of working atmosphereand discipline towardemployee work productivity pt. Duta margalestarindomedan, Journal of Advanced Research in Dynamical and Control Systems (2020), Pages:554-564. 